\title{
Implementasi Outdoor Learning untuk Meningkatkan Hasil Belajar Kognitif Mahasiswa pada Mata Kuliah Sistematika Tumbuhan Tinggi
}

\section{Implementation of Outdoor Learning to Improve Students Cognitive Learning Outcomes on High Plant Systematics Course}

\author{
Anwari Adi Nugroho*, Nur Rokhimah Hanik \\ Universitas Veteran Bangun Nusantara, Jalan Letjen Sujojo Humardani No.1 Kec.Sukoharjo, Sukoharjo, Indonesia \\ *email: bio_anwary@yahoo.com
}

Manuscript received: 6 Agusus 2016 Revision accepted: 3 Januari 2016

\begin{abstract}
Outdoor learning was learning that gives students the opportunity to explore the surrounding environment as a source of learning. Students are required to be able to construct knowledge independently throgh the process of exploring the learning environment in Systematics of High Plant. This research aims to improve student cognitive learning outcomes through the implementation of outdoor learning in the subject of High Plant Systematics. The method used was classroom action research with 3 cycles. Each cycle consists of four basic stages, namely planning, implementation, observation and reflection. Samples used in this study was 22 fourth semester students of Biology Education Study Program, Faculty of Teaching and Education, University of Veteran Bangun Nusantara Sukoharjo .The study was conducted in March and May 2015. The cognitive learning was measured through the posttest. The results showed that the cognitive learning outcomes of students increased from the first cycle to the second cycle amounted to $27.56 \%$ and from the second cycle to the third cycle of $10.20 \%$. Target of cognitive learning outcomes at least achieved grade of 75 in average.
\end{abstract}

Keywords: Outdoor learning, learning outcomes, Systematics of High Plant

\section{PENDAHULUAN}

Kualitas sumber daya menusia sangat ditentukan oleh kualitas pendidikan. Pendidikan yang bermutu dan berkualitas tidak lepas dari proses pembelajaran yang berlangsung di dalamnya (Asmawi, 2005). Proses pembelajaran dalam perguruan tinggi tercantum dalam Peraturan Menteri Ristek dan Dikti nomor 44 Tahun 2015 tentang Standar Nasional Pendidikan Tinggi pada Standar Proses Pembelajaran pasal 11 bahwa pembelajaran di perguruan tinggi bersifat interaktif, holistik, integratif, saintifik, kontekstual, tematik, efektif, kolaboratif dan berpusat pada mahasiswa. Mengacu pada peraturan tersebut. Dosen memiliki kewenangan penuh untuk mendesain pembelajaran yang inovatif agar pembelajaran menjadi berkualitas (Mustami, 2009).

Pembelajaran biologi sebagai sains memiliki pendekatan pembelajaran yang khusus sesuai dengan karakteristik biologi sebagai sains. Salah satu pembelajaran sains yaitu pembelajaran biologi menurut Rustaman (2005) menyatakan bahwa tujuan belajar dalam pembelajaran biologi dapat dicapai dengan mengoptimalkan proses pembelajaran biologi di dalam kelas. Proses pembelajaran biologi dituntut untuk lebih membuat peserta didik lebih aktif dan terlibat selama pembelajaran, Pembelajaran biologi menurut pandangan konstruktivis adalah pembelajaran yang menekankan pada pengetahuan tidak hanya dapat dipindahkan secara utuh dari pikiran pendidik ke mahasiswa sebagai pembelajar, tetapi secara aktif dibangun oleh mahasiswa melalui proses pembelajaran yang bermakna sebagai pengalaman nyata. Kompleksitas berpikir mahasiswa akan terberdayakan melalui kegiatan pembelajaran konstruktivis.

Kenyataannya proses pembelajaran biologi di perkuliahan sekarang belum sepenuhnya sesuai hakikat pembelajaran biologi. Pembelajaran biologi masih sering mengutamakan produk sehingga proses pembelajaran cenderung berpusat pada dosen. Pembelajaran biologi di kelas hanya dilakukan di kelas dan jarang diarahkan pada kegiatan observasi di lingkungan sekitar Salah satu mata kuliah yang diajarkan di Program Studi Pendidikan Biologi adalah Sistematika Tumbuhan Tinggi (STT). Hasil observasi proses pembelajaran mata kuliah mata kuliah Sistem Tumbuhan Tinggi (yang peneliti ampu) pada semester IV tahun akademik 2014/2015 di Program Studi Pendidikan Biologi Universitas Veteran Bangun Nusantara Sukoharjo ditemukan beberapa permasalahan. Selama pembelajaran pertemuan I dan II sub materi klasifikasi dan determinasi tumbuhan, mahasiswa kesulitan memahami materi dibuktikan dengan rata-rata hasil postest sebesar 60,70. Hasil tersebut cukup rendah karena target rata-rata hasil belajar kognitif sebesar 75,00 dengan skala 100 . Kondisi tersebut mengindikasikan bahwa hasil belajar kognitif mahasiswa semester IV pada mata kuliah Sistem Tumbuhan Tinggi masih rendah.

Permasalahan pembelajaran perlu dicari solusi agar terjadi perbaikan dan peningkatan hasil belajar kognitif. Sebelum penentuan solusi terhadap permasalahan perlu mengetahui akar masalah. Akar masalah dalam pembelajaran Sistem Tumbuhan Tinggi adalah belum adanya pembelajaran yang dapat meningkatkan hasil 
belajar kognitif. Sebagai dosen profesional dituntut untuk mampu menguasai berbagai pendekatan/model/metode pembelajaran yang sesuai untuk mengatasi permasalahan pembelajaran. Salah satu solusi yang dipilih untuk mengatasi permasalahan pembelajaran tersebut adalah dengan menerapkan pembelajaran aktif. Pembelajaran merupakan pembelajaran yang melibatkan mahasiswa untuk aktif membangun pengetahuan sendiri melalui berbagai kegiatan (Drake \& Battaglia, 2014). Pembelajaran aktif direkomendasikan dalam pembelajaran perguruan tinggi karena memberdayakan kemampuan termasuk kognitif mahasiswa (Harsono, 2008; Faust \& Paulson, 1998).

Husamah (2013) menyatakan bahwa Outdoor learning adalah pembelajaran yang mengajak peserta didik belajar di luar kelas untuk melihat peristiwa langsung di lapangan dengan tujuan mengakrabkan peserta didik dengan lingkungannya. Lingkungan di luar sekolah dapat dijadikan sebagai sumber belajar yang bersifat fakta, karena materi pembelajaran yang peserta didik pelajari di dalam kelas dapat ditemukan langsung di lapangan. Outdoor learning merupakan pembelajaran yang mampu membuat mahasiswa aktif dengan mengajak mahasiswa mengidentifikasi tumbuhan secara langsung sehingga pembelajaran menjadi bermakna dan penguasaan konsep atai hasil belajar kognitif dapat diberdayakan. Kerucut pengalaman Dale (2012) menyatakan bahwa orang akan mengingat $50 \%$ dari yang didengar dan dilihat, tetapi orang akan mengingat $90 \%$ dari yang telah lakukan seperti mengerjakan sebuah tugas atau melakukan penyelidikan.

Manfaat Outdoor Learning menurut Husamah (2013) adalah membangun makna (input), kemudian prosesnya melalui struktur kognitif sehingga berkesan lama dalam ingatan atau memori (terjadi rekonstruksi). Kegiatan pengamatan langsung dapat memperkuat daya retensi pengetahuan jika dibandingkan dengan hanya mendengar, sehingga meningkatkan hasil belajar kognitif (Nicolls, 2004). Outdoor learning merupakan pembelajaran yang menyenangkan bagi mahasiswa. Sesuai pernyataan Kertamuda (2008) bahwa pembelajaran yang tidak disukai dan tidak menyenangkan membuat mahasiswa merasa stress dan kurang menikmati pembelajaran yang diikuti dan menyebabkan hasil belajar yang didapatkan juga mengalami penurunan.

Mata kuliah Sistematika Tumbuhan Tinggi merupakan mata kuliah semester IV di Program Studi Pendidikan Biologi Universitas Veteran Bangun Nusantara Sukoharjo dengan cakupan materi tentang struktur dan pengelompokan taksonomi tumbuhan tingkat tinggi (Phanerogamae) serta cara mendeterminasi spesies dengan mengamati ciri-ciri morfologi, anatomi, dan fisiologi dari suatu tumbuhan. Karakteristik kontekstual dan objek materi pembelajaran berupa tumbuhan tinggi yang mudah dijumpai di lingkungan sekitar. Lingkungan belajar untuk outdoor learning adalah keanekaragaman hayati tumbuhan tingkat tinggi di lingkungan Universitas Veteran Bangun Nusantara Sukoharjo. Keanekaragaman hayati tumbuhan tinggi di lingkungan Universitas Veteran Bangun
Nusantara Sukoharjo cukup tinggi seperti Famili Graminae, Solanaceae, Araceae, Arecaceae, Asteraceae, Mimosaceae, Papilionaceae, Orchidaceae, Musaceae, Rutaceae, yang sebagian besar terdapat di kebun hijau (Green House) Program Studi Pendidikan Biologi, sehingga memiliki potensi sebagai sumber belajar bagi mahasiswa.

\section{METODE PENELITIAN}

Penelitian ini merupakan bagian dari penelitian tindakan yang dilakukan di Program Studi Pendidikan Biologi Fakultas Keguruan dan Ilmu Pendidikan Universitas Veteran Bangun Nusantara Sukoharjo. Waktu penelitian dimulai bulan Maret sampai Mei 2015 yang terdiri dari 3 siklus. Masing-masing siklus terdiri dari 4 tahapan dasar yaitu perencanaan, pelaksanaan, pengamatan dan refleksi. Kompetensi Dasar yang digunakan untuk penelitian pada Mata Kuliah Sistematika Tumbuhan tinggi adalah menjelaskan ciri-ciri, taksonomi, dan sistematika tumbuhan Angiospermae. Sub materi pada Siklus I adalah materi Famili Graminae di seluruh wilayah Kampus Univet. Siklus II adalah famili selain Graminae di wilayah Kampus Univet sebelah barat. Siklus III adalah famili selain Graminae di wilayah Kampus Univet sebelah timur.

Subyek penelitian adalah mahasiswa Program Studi Pendidikan Biologi semester IV Fakultas Keguruan dan Ilmu Pendidikan Universitas Veteran Bangun Nusantara Sukoharjo Tahun Akademik 2014-2015 dengan jumlah 22 mahasiswa. Sumber data dalam penelitian adalah mahasiswa semester IV yang sedang menempuh Mata Kuliah Sistematika Tumbuhan Tinggi serta TIM dosen mata kuliah sebagai observer. Data dikumpulkan melalui postes yang dilakukan setiap akhir siklus untuk mengukur hasil belajar kognitif. Bentuk soal postes adalah essai yang berjumlah 10 soal. Hasil belajar kognitif mengacu pada Anderson dan Krathwohl (2010) yaitu mengingat, memahami, mengaplikasikan, menganalisis, mengevaluasi, dan mengkreasi. Target capaian hasil belajar kognitif yaitu nilai minimal rata-rata kelas sebesar 75 .

\section{HASIL DAN PEMBAHASAN}

Penelitian ini dilaksanakan pada mahasiswa Semester IV Program Studi Pendidikan Biologi Fakultas Keguruan dan Ilmu Pendidikan Universitas Veteran Bangun Nusantara Sukoharjo Tahun Akademik 2014-2015. Pada penelitian ini diawali dengan observasi terhadap kondisi awal pembelajaran pada mahasiswa semester IV pada sub materi klasifikasi dan determinasi tumbuhan bahasan keanekaragaman hayati.

\section{Pra Tindakan (Pra Siklus)}

Kondisi awal pembelajaran pertemuan I tanggal 11 Maret 2015 dan pertemuan II tanggal 18 Maret 2015 pada sub materi klasifikasi dan determinasi tumbuhan, mahasiswa kesulitan memahami materi dibuktikan dengan rata-rata hasil postes sebesar 60,70. Hasil tersebut cukup rendah karena target rata-rata hasil belajar kognitif sebesar 75,00 dengan skala 100. Kondisi tersebut mengindikasikan bahwa hasil belajar kognitif mahasiswa semester IV pada 
mata kuliah Sistematika Tumbuhan Tinggi masih rendah. Pembelajaran Tumbuhan Tinggi masih mengutamakan produk sehingga proses pembelajaran cenderung berpusat pada dosen. Pembelajaran biologi di kelas hanya dilakukan di kelas dan jarang diarahkan pada kegiatan observasi di lingkungan sekitar.

\section{Tindakan (Siklus I, Siklus II, dan Siklus III)}

Penelitian dilaksanakan selama tiga siklus dan setiap siklus dilaksanakan dalam 2 pertemuan. Pelaksanaan tindakan tiap siklus terdiri dari perencanaan (planning), pelaksanaan (acting), observasi (observing), dan refleksi (reflecting). Siklus I dilaksanakan pada tanggal 8 dan 15 April 2015 dengan mengindentifikasi tumbuhan Graminae di lingkungan Univet Bantara Sukoharjo. Tahap perencanaan siklus I adalah menyusun perangkat pembelajaran meliputi Silabus, Rencana Pelaksanaan Pembelajaran (RPP) dan soal postes.. Pelaksanaan tindakan siklus I pada pertemuan pertama dilaksanakan kegiatan diluar kelas sedangkan pertemuan kedua ada presentasi di kelas. Kelas dibagi menjadi 5 kelompok dengan anggota kelompok yang heterogen tingkat akademiknya (tinggi, sedang, rendah). Pertemuan pertama di dalam kelas, dosen menyampaikan tujuan pembelajaran dan mengarahkan mahasiswa sebelum mengamati tumbuhan Graminae di kampus. Mahasiswa berkelompok mengamati tumbuhan yang termasuk Graminae di sekitar kampus dan setiap kelompok mendapat lokasi pengamatan yang berbeda. Pengamatan secara langsung menggunakan indera kemudian mencatat deskripsi tumbuhan Famili Graminae serta mendokumentasikannya. Selama melakukan pengamatan, mahasiswa menggunakan referensi buku serta bantuan internet untuk membantu melakukan pendataan deskripsi tumbuhan. Beberapa tumbuhan yang sulit untuk diidentifikasi di lokasi pengamatan, maka diambil sampel tumbuhannya dan melakukan pengataman di dalam kelas. Pertemuan kedua mencakup kegiatan presentasi kelompok hasil pengamatan, diskusi dan tanya jawab, konfirmasi dari dosen, penyimpulan bersama kemudian evaluasi berupa postes untuk mengukur kemampuan kognitif mahasiswa. Tahap observasi dilaksanakan pada proses pembelajaran berlangsung dengan mengamati keterlaksanaan Outdoor Learning. Hasil postes diperoleh nilai rata-rata kelas sebesar 77, 95 (skala 100) dengan target nilai sebesar 75 (skala 100). Tahap refleksi siklus I adalah kegiatan Ourdoor Learning berlangsung dengan baik mulai dari kegiatan pengamatan di luar kelas sampai postes. Namun ditemukan kekurangan selama pembelajaran berlangsung yaitu mahasiswa masih kesulitan memahami langkahlangkah pembelajaran dan mengakibatkan pembelajaran selesai tidak tepat waktu sehingga untuk siklus II dosen perlu memperjelas instruksi kegiatan pembelajaran.

Siklus kedua dilaksanakan tanggal 22 dan 29 April 2015 dengan mengindentifikasi tumbuhan selain Graminae di lingkungan Univet Bantara Sukoharjo sebelah barat. Tahap perencanaan siklus II adalah menyusun perangkat pembelajaran meliputi Silabus, Rencana Pelaksanaan Pembelajaran (RPP) berdasarkan refleksi siklus I dan soal postes. Pelaksanaan pembelajaran pertemuan pertama, kelompok melakukan pengamatan tumbuhan tinggi selain famili Graminae di lingkungan kampus bagian barat.
Beberapa tumbuhan tinggi diidentifikasi selama pengataman seperti Famili Papilionaceae, Mimosaceae, Araceae, Musaseae, Rutaceae, Arecaceae, Zingiberaceae, Asteraceae. Tumbuhan yang sulit diidentifikasi langsung di lapangan, sampel tumbuhan dibawa ke kelas untuk diidentifikasi. Pertemuan kedua adalah kegiatan presentasi, diskusi, tanya jawab dan penyimpulan materi. Siklus II mahasiswa sudah memahami langkah-langkah pembelajaran sehingga berlangsung tepat waktu dan lancar. Tahap observasi dilaksanakan pada proses pembelajaran berlangsung dengan mengamati keterlaksanaan Outdoor Learning. Hasil postes diperoleh nilai rata-rata kelas sebesar 80,00 (skala 100) dengan target nilai sebesar 75 (skala 100). Refleksi siklus II yaitu pada saat presentasi, mahasiswa belum maksimal dalam menyampaikan informasi sehingga pada siklus III dosen perlu menegaskan kepada kelompok yang presentasi untuk lebih jelas dan detail dalam penyampaiannya.

Siklus ketiga dilaksanakan tanggal 6 dan 13 Mei 2015 dengan mengindentifikasi tumbuhan selain Graminae di lingkungan Univet Bantara Sukoharjo sebelah timur. Pelaksanaan pembelajaran pertemuan pertama adalah pengamatan tumbuhan tinggi selain famili Graminae di lingkungan kampus sebelah timur. Beberapa tumbuhan tinggi diidentifikasi selama pengataman seperti Famili Cyperaceae, Solanaceae, Mimosaceae, Araceae, Musaseae, Orchidaceae, Rutaceae, Arecaceae, Caesalpiniaceae, Asteraceae. Pertemuan kedua adalah kegiatan presentasi, diskusi, tanya jawab dan penyimpulan materi. Kegiatan presentasi pada siklus III, mahasiswa menyampaikan materi dengan jelas dan detail. Tahap observasi dilaksanakan pada proses pembelajaran berlangsung dengan mengamati keterlaksanaan Outdoor Learning. Hasil postes diperoleh nilai rata-rata kelas sebesar 89,09 (skala 100) dengan target nilai sebesar 75 (skala 100).

Hasil belajar mata kuliah Sistem Tumbuhan Tinggi yang diukur fokus pada hasil belajar kognitif. Hasil belajar kognitif diukur dengan postes disetiap akhir siklus. Instrumen postes berupa soal essai berjumlah 10 soal. Hasil belajar kognitif mahasiswa dapat dilihat pada Tabel 1 .

Tabel 1. Hasil Belajar Kognitif

\begin{tabular}{|c|c|c|c|c|}
\hline \multirow[b]{2}{*}{ Nilai } & \multicolumn{3}{|c|}{ Siklus } & \multirow[b]{2}{*}{$\begin{array}{c}\text { Target } \\
\text { (skala 100) }\end{array}$} \\
\hline & $\begin{array}{c}\text { Siklus } \\
\text { I }\end{array}$ & $\begin{array}{c}\text { Siklus } \\
\text { II }\end{array}$ & $\begin{array}{c}\text { Siklus } \\
\text { III }\end{array}$ & \\
\hline Jumlah & 1715 & 1760 & 1960 & \\
\hline $\begin{array}{l}\text { Rata-rata } \\
\text { (skala 100) }\end{array}$ & 77,95 & 80,00 & 89,09 & 75 \\
\hline Peningkatan & & 27,56 & 10,20 & \\
\hline
\end{tabular}

Tabel 1 menunjukkan bahwa terjadi peningkatan hasil belajar kognitif dari siklus I ke siklus II sebesar 27,56\% dan siklus II ke siklus III sebesar 10,20\%. Hasil belajar kognitif siklus I sampai siklus III juga telah memenuhi target ratarata nilai kognitif sebesar 75 .

Outdoor Learning merupakan pembelajaran relevan dengan karakteristik mata kuliah Sistem Tumbuhan Tinggi yang bersifat kontekstual. Tumbuhan tinggi yang dijadikan 
objek belajar mahasiswa merupakan tumbuhan tinggi yang terdapat di lingkungan Universitas Veteran Bangun Nusantara Sukoharjo. Tumbuhan tinggi di Univer Bantara Sukoharjo cukup tinggi sehingga perlu dimanfaatkan keanekaragaman tumbuhannya sebagai sumber belajar. Pembelajaran dengan menggunakan objek secara langsung yaitu tumbuhan di lingkungan sekitar membuat mahasiswa lebih antusias dalam pembelajaran. Outdoor learning dengan proses pembelajaran luar kelas yaitu belajar secara langsung mengamati tumbuhan tinggi di lingkungan Univet Bantara Sukoharjo sehingga menjadikan pembelajaran lebih bermakna.

Hasil pada Tabel 1 menunjukkan bahwa terjadi peningkatan hasil belajar kognitif. Peningkatan hasil belajar kognitif dikarenakan pembelajaran lebih memusatkan mahasiswa sebagai pembelajar, mahasiswa tidak hanya mendengarkan, tetapi juga mengamati, mengidentifikasi menganalisis, hingga mengkomunikasikan konsep yang didapat. Sesuai dengan hasil penelitian dari Nastiti et el., (2012); Bambang dan Anwar (2009) yang menyatakan bahwa pembelajaran dengan menggunakan proses penemuan akan dapat menigkatkan pemahaman konsep serta kemampuan memecahkan masalah oleh peserta didik. Hasil penelitian Hussain dan Akhtar (2013) menyatakan bahwa aktivitas hands on peserta didik selama pembelajaran dapat meningkatkan minat dan pemahaman peserta didik yang pada akhirnya menghasil motivasi dan prestasi sains yang tinggi. Silberman (2008) menjelaskan bahwa otak bukan hanya menerima informasi, melainkan memproses dan mengolahnya. Kegiatan yang mendukung otak untuk mengolah informasi secara efektif antara lain apabila mahasiswa berdiskusi dan mengajukan pertanyaan berkaitan dengan materi diskusi. Otak perlu menghubungkan apa yang diajarkan dengan yang sudah diketahui dan proses berpikir. Otak perlu menguji informasi, menyimpulkan atau menjelaskan kepada orang lain. Pembelajaran Outdoor Learning mahasiswa tidak hanya mengidentifikasi tumbuhan secara individu tetapi juga berdiskusi dengan teman dan berinteraksi dengan dosen. Hasil tersebut didukung oleh Daniel (2013), Akanmu et al., (2013) dan Hackathorn et al., (2011) yang menyatakan bahwa pembelajaran yang dilakukan bersamasama akan menunjukkan hasil belajar yang lebih efektif dari pada pembelajaran individual atau metode ceramah. Hasil penelitian yang dilakukan oleh Kao et al., (2008) menyimpulkan bahwa melalui knowledge sharing (kegiatan kelompok) mahasiswa lebih termotivasi untuk memperluas pengetahuannya. Hasil penelitian tersebut menyebutkan bahwa kegiatan knowledge sharing dapat meningkatkan partisipasi aktif mahasiswa dalam pembelajaran dan meningkatkan hasil belajar pada ranah kognitif (understanding,conceptual organization, and reflection). Outdoor learning memfasilitasi mahasiswa untuk berinteraksi dengan lingkungan sekitar sehingga mahasiswa mengeksplorasi pengetahuan secara mandiri maupun secara kelompok. Harsono (2008) menyatakan bahwa pembelajaran interaktif terjadi dalam berbagai bentuk, antara lain antara mahasiswa dengan materi pembelajaran, antara mahasiswa dengan aktivitas pembelajaran, antara mahasiswa dengan dosen/fasilitator, dan antar mahasiswa. Pembelajaran interaktif juga memfasilitasi setiap mahasiswa untuk mengerjakan sesuatu sesuai dengan pengetahuan atau materi yang sedang dipelajarinya, sehingga mendukung mahasiswa memperoleh pengetahuan secara maksimal.

Outdoot Learning juga memfasilitasi mahasiswa untuk menyampaikan dan menjelaskan hasil penyelidikannya kepada kelompok lain melalui kegiatan presentasi. Hasil penelitian Magnesen dalam Nicolls (2004) menjelasakan bahwa tingkat ingatan peserta didik yang belajar dengan melakukan dan mengkomunikasikannya sangat efektif yaitu mencapai sebesar 90\%, sebaliknya apabila peserta didik belajar hanya dengan mendengar, membaca atau melihat maka tingkat ingatan siswa kurang dari 50. Outdoor Learning, mahasiswa belajar secara berkelompok dalam melakukan identifikasi di luar kelas hingga melakukan presentasi. Dosen mengarahkan mahasiswa untuk melakukan identifikasi secara kelompok dan tidak membatasi proses identifikasi oleh mahasiswa dalam hal sumber informasi. Mahasiswa tidak hanya belajar untuk bekerja sama tetapi juga harus bertanggung jawab kepada teman satu kelompoknya dalam tercapainya pengetahuan yang merata (Barkley et al., 2005). Tahap presentasi memberi kesempatan pada mahasiswa untuk bertukar informasi karena selama presentasi terjadi interaksi melalui tanya jawab sehingga pengetahuan mahasiswa dapat meningkat.

\section{KESIMPULAN}

Implementasi Outdoor Learning pada pembelajaran Sistem Tumbuhan Tinggi mampu meningkatkan hasil belajar kognitif mahasiswa. Hasil penelitian menunjukkan bahwa terjadi peningkatan hasil belajar kognitif mahasiswa dari siklus I ke siklus II sebesar $27,56 \%$ dan dari siklus II ke siklus III sebesar 10,20\%. Target capaian hasil belajar kognitif tercapai yaitu nilai minimal rata-rata kelas sebesar 75 .

\section{UCAPAN TERIMA KASIH}

Peneliti mengucapkan terima kasih kepada Program Studi Pendidikan Biologi, Fakultas Keguruan dan Ilmu Pendidikan, Universitas Veteran Bangun Nusantara serta pihak-pihak yang tidak dapat disebutkan satu persatu, yang telah mendukung penelitian dari awal sampai akhir.

\section{DAFTAR PUSTAKA}

Anderson, L.W. \& Krathwohl, D.R. (2010). Kerangka Landasan Untuk Pembelajaran, Pengembangan, dan Assesmen: Revisi Taksonomi Pendidikan Bloom. Yogyakarta: Pustaka Pelajar.

Akanmu \& Fejenidagba. (2013). Guided-discovery Learning Strategy and Senior School Students Performance in Mathematics in Ejigbo, Nigeria. Department of Science Education, Faculty of 
Education, University of Ilorin, Ilorin, Nigeria. Journal of Education and Practice. Vol.4(12).

Asmawi, M.R. (2005). Strategi Meningkatkan Lulusan Bermutu di Perguruan Tinggi. Makara, Sosial Humaniora, Vol. 9 (2), Desember 2005: 66-71.

Bambang S. \& Anwar S. (2009). Pengembangan Model Pembelajaran Discovery Learning Ilmu Pendidikan untuk Meningkatkan Pemahaman Konsep Pendidikan Mahasiswa PGSD FIP UNY. Fakultas Ilmu Pendidikan Universitas Negeri Yogyakarta. Jurnal Penelitian Ilmu Pendidikan 2(1), 54.

Barkley, E.F., Cross, K.P., \& Major, C.H. (2005). Collaborative Learning Techniques.USA: JosseyBass.

Dale, S. H. (2012). Learning Theories-A Perspective Education (Terjemahan). Yogyakarta: Pustaka Media.

Daniel, P.B. (2003). The Effect of Implementing The Cooperative Learning Struture, Numbered Head Together, in Chemestry Classes at a Rural, Low Performing High School. The Interdeparmental Program in Natural Sciences. Lousiana State University.

Drake, E., \& Battaglia, D. (2014). Teaching and Learning in Active Learning Classrooms. The Faculty Center for Innovative Teaching: Central Michigan University

Faust, J.L \& Paulson, D.R. Active Learning in the College Classroom. Journal on Excellence in College Teaching, Vol.9 (2): 3-24.

Hackathorn, J., Solomon, E.D., \& Blankmeyer, K.L. (2011). Learning by Doing: An Empirical Study of Active Teaching Techniques. The Journal of Effective Teaching. Vol. 11(2): 40-54.

Harsono. (2008). Student-Centered Learning di Perguruan Tinggi. Jurnal Pendidikan Kedokteran dan Profesi Kesehatan Indonesia. Vol. 3(1), Maret 2008.
Hussain, M. \& Akhtar, M. (2013). Impact of Hands-on Activities on Students' Achievement in Science: An Experimental Evidence from Pakistan. Middle-East Journal of Scientific Research .16 (5): 626-632, ISSN 1990-9233.

Husamah. (2013). Pembelajaran Luar Kelas Outdoor Learning. Jakarta: Prestasi Pustaka raya.

Kao, Gloria Yi-Ming, Sunny, Lin, S.J., \& Chuen-Tsai Sun. (2008). Beyond sharing: Engaging Students in Cooperative and Competitive Active Learning, Journal of Educational Technology \& Society, 11(3), 82-96.

Kertamuda, F. (2008). Pengaruh Motivasi Belajar Terhadap Hasil Belajar. Jurnal Psikologi 21(1):25-38.

Nastiti, S., Antonius, \& Woro, S. (2012). Efektifitas Model Pembelajaran Guided Discovery Learning terhadap Kemampuan Memecahkan Masalah Kimia. Jurusan KIMIA FP MIPA Universitas Negeri Semarang. Chemistry in Education 2(1), 49-55.

Nicolls, M. (2004). A second chance: AL in Iraq. Creative Associates International. Paper of Education, Mobilization, and Communication Division, July.

Kementerian Pendidikan dan Kebudayaan, Republik Indonesia. (2013). Peraturan Menteri Pendidikan dan Kebudayaan Republik Indonesia Tentang Standar Nasional Pendidikan Tinggi (SNPT). Jakarta.

Kementerian Hukum dan HAM. (2005). Republik Indonesia. Undang-Undang Guru dan Dosen Nomor 14 Tahun 2005.

Rustaman, N.Y. (2005). Stategi belajar Mengajar Biologi. Malang: UM Press.

Silberman, M. (2008). 101 Strategi Pembelajaran Aktif. Yogyakarta: Pustaka pelajar. 